\title{
TOMOGRAPHIC ANALYSIS OF T-1 VERTEBRA TO INSERT LAMINAR SCREWS IN CHILDREN FROM O TO 12 YEARS
}

\author{
ANÁLISE TOMOGRÁFICA DA VÉRTEBRA T-1 PARA PASSAGEM DE PARAFUSOS LAMINARES \\ EM CRIANÇAS DE O A 12 ANOS
}

\author{
ANÁLISIS TOMOGRÁFICO DE LA VÉRTEBRA T-1 PARA PASAR TORNILLOS \\ LAMINARES EN NIÑOS DE O A 12 AÑOS
}

Luiz Roberto Delboni Marchese ${ }^{1}$, Olavo Biraghi letalF ${ }^{1}$, Raphael Martus Marcon ${ }^{1}$, Alexandre Fogaça Cristante ${ }^{1}$, Reginaldo Perilo Oliveira ${ }^{1}$,

Tarcísio Eloy Pessoa de Barros FILHo ${ }^{1}$

\begin{abstract}
Objective: Tomographic analysis of the T1 vertebra in children from 0 to 12 years of age, in order to obtain anatomical parameters that assist intralaminar fixation in this pediatric population. Methods: Retrospectively analysis of the spine with CT (cervical and thoracic) of individuals aged between 0 and 12 years old, of both sexes, without anatomical deformities. The CT scans were evaluated separately, on each side, for length and thickness of the laminas as well as spinolaminar angle. The morphometric analysis was performed with iSite PACS Philips Healthcare Informatics ${ }^{\circledR}$ program and the values were expressed in millimeters (mm). The variables were correlated with age groups and sex of individuals. Statistical analysis was performed using t test and the results were considered significant when $p<0.05$. Results: By means of tomographic analysis of 24 patients it was found that age has no correlation with the angle of attack for intralaminar screws T1. However, the length and thickness of the T1 lamina increase proportionally with age. The total average length of the laminas was $28.62 \pm 4.42 \mathrm{~mm}$. The total average thickness was $4.75 \pm 0.95 \mathrm{~mm}$ (3.2 to 6.5). Conclusion: This study shows relevant data on the use of Tran laminar screws currently commercially available with a minimum thickness of $3.5 \mathrm{~mm}$. It is thus possible to say in this sample, they can be used in $87.5 \%$ of all laminas, being applicable in all lamina in patients older than 44 months of age.
\end{abstract}

Keywords: Cervical thoracic transition; Tomographic analysis, T1 lamina Tomography X-ray computed; Cervical vertebrae; Thoracic vertebrae; Laminectomy.

\section{RESUMO}

Objetivo: Análise tomográfica da vértebra T1 em crianças de zero a doze anos de idade, obtendo parâmetros anatômicos que auxiliarão a fixação intralaminar nessa população infantil. Métodos: Análise retrospectiva da coluna por TC (cenvical e torácica) de indivíduos entre 0 e 12 anos de idade, de ambos os sexos, sem deformidades anatômicas. Foram avaliados, separadamente, em cada lado, o comprimento e a espessura das lâminas, bem como o ângulo espino-laminar. A análise morfométrica foi realizada com o programa iSite PACS Philips Healthcare Informatics ${ }^{\circledR}$ e os valores obtidos foram expressos em milímetros $(\mathrm{mm})$. As variáveis estudadas foram correlacionadas com os grupos etários e o sexo dos indivíduos. A análise estatística foi feita pelo teste $t$ e os resultados foram considerados significativos quando $p<0,05$. Resultados: Por meio de análises tomográficas de 24 pacientes, verificou-se que a idade não tem correlação com o ângulo de ataque para parafusos intralaminares de T1. Já o comprimento e a espessura da lâmina de T1 aumentam proporcionalmente com a idade. O comprimento médio total das lâminas foi de 28,62 \pm 4,42 mm. A média total da espessura 4,75 $\pm 0,95 \mathrm{~mm}$ (3,2 a 6,5). Conclusão: O presente estudo mostra dados relevantes sobre a utilização de parafusos translaminares, que atualmente são disponíveis comercialmente com espessura mínima de 3,5 mm. É possível, assim, afirmar que, nesta amostra, pode ser utilizado em 87,5\% do total de lâminas, sendo aplicável em todas as lâminas nos pacientes acima de 44 meses de idade.

Descritores: Transição cérvico-torácica; Análise Tomográfica, Lâmina T1 Tomografia computadorizada por raio X; Vertebras cervicais; Vertebras torácicas; Laminectomia.

\section{RESUMEN}

Objetivo: Análisis tomográfico de la vértebra T1 en niños de cero a doce años de edad, para obtener parámetros anatómicos que ayudarán la fijación con tornillos intralaminares en esta población infantil. Métodos: Análisis retrospectivo de la columna por TAC (cervical y torácica) de individuos entre 0 y 12 años de edad, de ambos sexos, sin deformidades anatómicas. Se evaluaron por separado, en cada lado, la longitud y el grosor de las láminas, así como el ángulo espinolaminar. El análisis morfométrico se realizó con el programa iSite PACS Philips Healthcare Informatics ${ }^{\circledR}$ y los valores se expresaron en milímetros $(\mathrm{mm})$. Las variables se correlacionaron con los grupos de edad y sexo de los individuos. Se realizó un análisis estadístico mediante la prueba t y los resultados se consideraron significativos cuando $p<0,05$. Resultados: Por medio de análisis tomográficos de 24 pacientes, se encontró que la edad no se correlaciona con el ángulo de ataque para tornillos intralaminares T1. Sin embargo, la longitud y el grosor de la lámina T1 aumentan proporcionalmente con la edad. La longitud promedio total de las láminas fue 28,62 \pm 4,42 mm. El espesor promedio total fue 4,75 $\pm 0,95 \mathrm{~mm}(3,2$ a 6,5). Conclusión: Este estudio muestra datos relevantes sobre el uso de tornillos translaminares que actualmente están disponibles en el mercado con un espesor mínimo de 3,5 mm. Por tanto, es posible afirmar que, en esta muestra, se puede utilizarlos en el 87,5\% de todas las láminas siendo aplicable en todas las láminas de pacientes mayores de 44 meses de edad.

Descriptores: Transición torácico cenvical; Análisis tomográfico; lámina T1 Tomografía computarizada por rayos X; Vértebras cervicales; Vértebras torácicas; Laminectomía.

1. Universidade de São Paulo, School of Medicine, Department of Orthopedics andTraumatology, São Paulo, SP, Brazil.

Study conducted at the University of São Paulo, School of Medicine, Department of Orthopedics and Traumatology, Spinal Deformities Group, SP, Brazil. Correspondence: Rua Dr. Ovidío Pires de Campos, 333, 2 Andar - CENATRA. Cerqueira Cesar, São Paulo, SP, Brazil. 05403-010. luizmarchese@yahoo.com.br 


\section{INTRODUCTION}

The cervicothoracic region is often affected by traumatic pathologies, tumors, and deformities. This location is difficult to visualize, requiring special radiographic views. Some examples are radiography with a swimmer's view and lower traction radiography of the upper limbs, or even the need for computed tomography. Its proximity to vital structures, such as the esophagus, trachea, and blood vessels, poses an obvious risk for the implantation of materials, making it a focus of intense research.

The $\mathrm{T} 1$ vertebra is located in a region of significant transition because it is situated between the cervical spine, which is relatively mobile, and the more rigid thoracic spine. This difference in stability between the spinal sections causes greater mechanical stress on the commonly used posterior approach fixation implants located in this transition. ${ }^{1}$ There are various techniques that enable fixation of the cervicothoracic transition by the posterior route. ${ }^{2-4}$ The methods currently most used are those that use screws, which can be fixed to the lateral masses or to the pedicles. ${ }^{3,5}$ These methods have limitations due to the high levels of related complications, ${ }^{6}$ which include loosening of the material, neurological risk, and a long technical learning curve.

There is information in the literature about the anatomical characteristics of the spine in studies with cadavers of adults. ${ }^{7-11}$ Panjabi et $a .1^{8-10}$ detailed most of the bone structures of the spine, but not of the laminae. Zindrick et al. ${ }^{11}$ quantified the height and thickness of the laminae, the interlaminar distance, and the epidural space in the thoracic spine, in a study of factors that interfere with the penetration of steel wires used for interlaminar ligatures in the spinal canal. The authors evaluated the spine in 13 cadavers, and reported average values of 18-24 $\mathrm{mm}$ for the height of the laminae (supero-inferior diameter) and 7-8 mm for laminar thickness (antero-posterior diameter).

Another quantitative anatomical study of spinal laminae was conducted by Xu et al., ${ }^{7}$ in 1999 , before the prospect of using intralaminar screws. The authors evaluated all the spinal laminae from C2 to L5 in 37 cadavers. However, some limitations of that study should be highlighted: the length of the lamina was evaluated from the middle part of the spinous process to the medial edge of the facet joint, which does not correspond to the diameter of the screw, which is placed through the contralateral lamina; the thickness of the lamina was measured at its midpoint, without any reference to the thinnest part of the lamina; and the number of cases evaluated was relatively small.

To our knowledge, there is no national or international study in the literature that has analyzed the linear and angular parameters of the spine at the cervicothoracic transition in the Brazilian pediatric population. Thus, the objective of this study was to quantitatively evaluate the linear and angular dimensions of the T1 lamina in individuals between 0 and 12 years of age, providing the epidemiological data for this population, and other information that might be useful for decision-making in daily surgical practice.

\section{MATERIAL AND METHODS}

We conducted a retrospective analysis of 27 CT scans performed in the routine outpatient care and emergency services of Hospital das Clínicas complex of the School of Medicine of Universidade de São Paulo (HC FMUSP). Data from exams conducted for other reasons was obtained with the approval of the scientific and ethics committees of Hospital das Clínicas. (CAAE:32437914.1.0000.0068)

Patients aged between 0 and 12 years were selected by convenience sampling, in consecutive form, and the data on the age and sex of the patients were reported. Cases with fractures of the T1 cervicothoracic transition, with or without fixation, or with spinal abnormalities such as deformities, neoplasias in the C7-T1 vertebrae, or rheumatological diseases, were excluded. Of the 27 tomographies analyzed, three were excluded from the evaluation because they displayed one or more of the exclusion criteria.

The linear and angular dimensions of the T1 laminae of the cervicothoracic spine were evaluated in the axial cuts of the CT scan where the lamina was thinner. The spinolaminar angle (measurement A) was plotted for both sides, with one of the lines at the inside of the T1 laminae parallel to the cortical surfaces of these laminae and the other line passing through the center of the spinous process. (Figure 1) The length of the lamina (measurement B) was measured in the axial cut of T1. The measurement was taken from the cortical surface opposite the lamina to the limit of the length visible in that cut, as shown in Figure 2. The thickness of the T1 laminae (measurement $\mathrm{C}$ ) was evaluated in millimeters $(\mathrm{mm})$. The measurements were obtained at the point of least thickness between the internal cortical layers (Figure 2). Each measurement was specifically evaluated for each side of the lamina. The morphometric analysis was performed using the iSite PACS Philips Healthcare Informatics ${ }^{\circledR}$ program.

Measurement A: spinolaminar angle (The spinolaminar angle was plotted for both sides, between a line inside the T1 lamina parallel to the corticals of this lamina, and a line parallel to the longitudinal axis of the spinous process of this vertebra). (Figure 1)

Measurement B: Length of the lamina (from the cortical opposite the lamina to the limit of its visible length, in the cut of least laminar thickness, specific to each side). (Figure 2)

Measurement C: Thickness of the lamina (measured between the corticals of the lamina in the cut of least thickness, specifically for each side. (Figure 2)

The statistical analysis was performed using SPSS 13.0 for Windows. Data on the average, standard deviation, minimum and

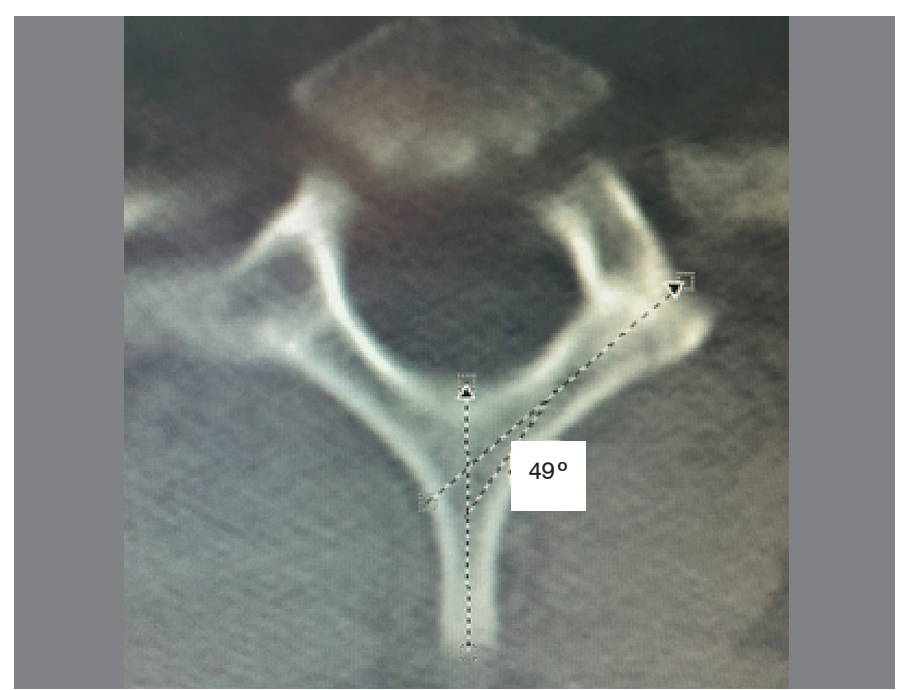

Figure 1. Measurement of the spinolaminar angle (measured bilaterally).

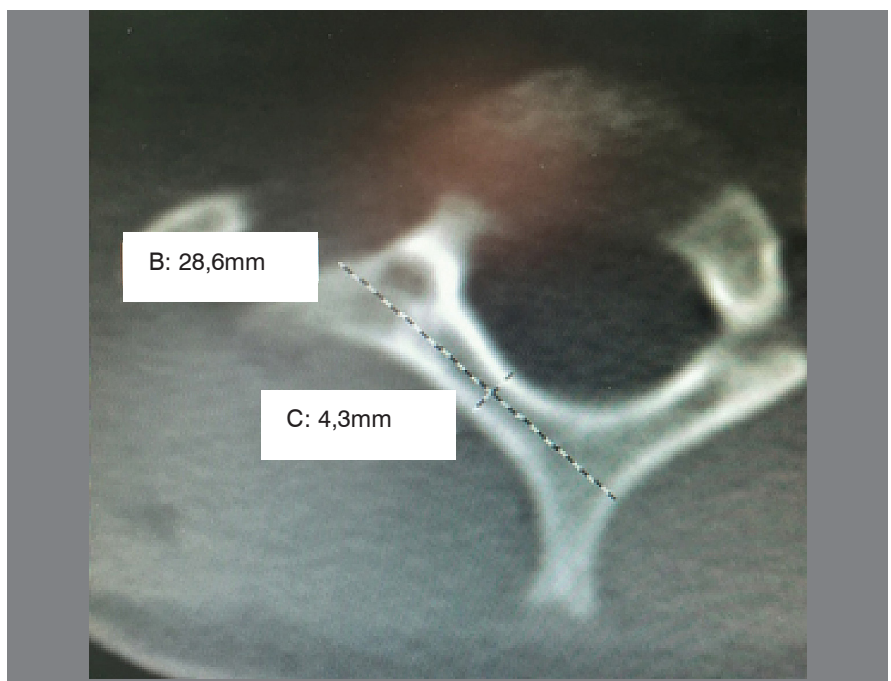

Figure 2. Measurement of the length (B) and of the thickness (C) of the lamina (measured bilaterally). 
maximum values were calculated. The values obtained for each of the variables were correlated with the age groups and sexes of the individuals. The comparisons were made using the Student's t test and the results were considered significant when $p<0.05$

\section{RESULTS}

We analyzed 27 tomographies, three of which were excluded, two because of congenital anatomical alterations in the region and one because of a neoplasia in the region. The remaining 24 tomographies, 15 of male patients and 9 of female patients, were analyzed. The average age of the patients was 68.83 months (ranging from 1 to 138 months). The age distribution of the 24 cases analyzed can be seen in the charts.

There was no difference in the angle of attack for the intralaminar $\mathrm{T} 1$ screws by sex, $p=0.31$, as can be seen in Figure 3 . The total average angle of attack for intralaminar T1 screws was $50.73 \pm 3.51$ (44 to 61 ) degrees. Boys had an average of $51.1 \pm 3.92$ (44 to 61) degrees and girls an average of 50.11 \pm 2.69 (44 to 56) degrees. In this study, we encountered a statistically significant difference, $p=0.012$, between the average angle of attack for the passage of the laminar screw on the right side of $50.21 \pm 3.37$ (44 to 59) degrees and on the left side of $51.25 \pm 3.65$ (44 to 61 ) degrees. The Kolgomorov-Smirnov normality test showed that the distribution of the data was normal for the angle and the age. The correlation analysis showed neither an increase nor a decrease in the angle of attack with age, $p=0.53$.

The average total length of the laminae, displayed in Figure 4, was $28.62 \pm 4.42 \mathrm{~mm}$. The length of the T1 laminae was $28.48 \pm 4.79$ (16.6 to 36.2 ) $\mathrm{mm}$ for the right side and $28.78 \pm 4.12$ (18.1 to 35.7) $\mathrm{mm}$ for the left side. The length was shorter in the females than in the males with averages of $27.07 \pm 3.82$ (18.1 to 32.1$) \mathrm{mm}$ and $29.56 \pm 4.55$ (16.6 to 36.2 ) $\mathrm{mm}$, respectively, with $p<0.01$. Analysis of the correlation showed that the older the individual, the greater the length of the T1 lamina, Pearson $=0.68, p<0.01$.

The average total thickness was $4.75+0.95$ (3.2 to 6.5$) \mathrm{mm}$. The average thickness of the T1 laminae was $4.71+0.94$ (3.2 to 6.3) $\mathrm{mm}$ on the right side and $4.80+0.98$ (3.2 to 6.5) $\mathrm{mm}$ on the left side. The results of the variance of the thickness and the frequency of the measurements obtained are shown in Figures 5 and 6. The thickness was less in the females than in the males with averages of $4.58+1.02$ (3.2 to 6.2 ) $\mathrm{mm}$ and $4.85+0.91$ (3.3 to 6.5$) \mathrm{mm}$, respectively, with $p<0.01$. For thickness, the comparison by sex

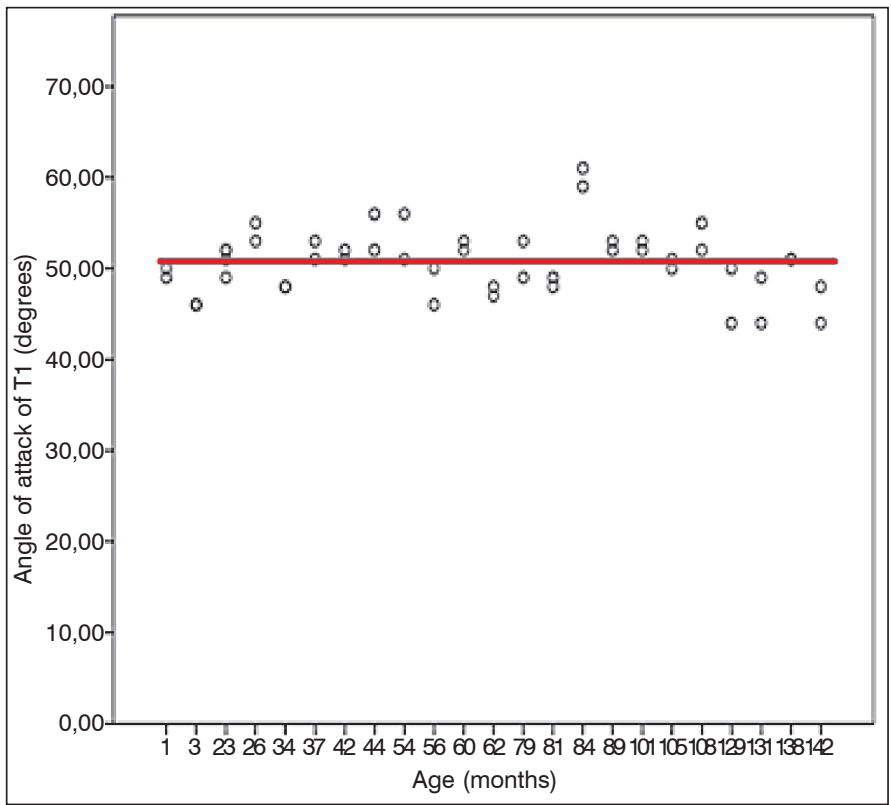

Figure 3. Variance in the angle of attack for intralaminar T1 screws, in degrees, by age. was not statistically significant, $p=0.33$. The correlation analysis showed that the older the individual, the greater the thickness of the $\mathrm{T} 1$ lamina, Pearson $=0.66, \mathrm{p}<0.01$.

\section{DISCUSSION}

The region of the cervicothoracic transition is characterized by an intermediate zone between the cervical lordosis and the thoracic kyphosis, which leads to a transfer of the load to the posterior arc. ${ }^{12}$ This causes an increase in mechanical stress in this transitional region, which added to the anatomical variations, leads to technical difficulties for the passage and effective fixation of screws, prompting the search for options to stabilize of this region.

The biggest challenge in using transpedicle screws in the cervicothoracic region is the technical difficulty of inserting the screws. The small size of the pedicles and the angle of attack for insertion of the screws complicates the surgery. Use of intraoperative radios-

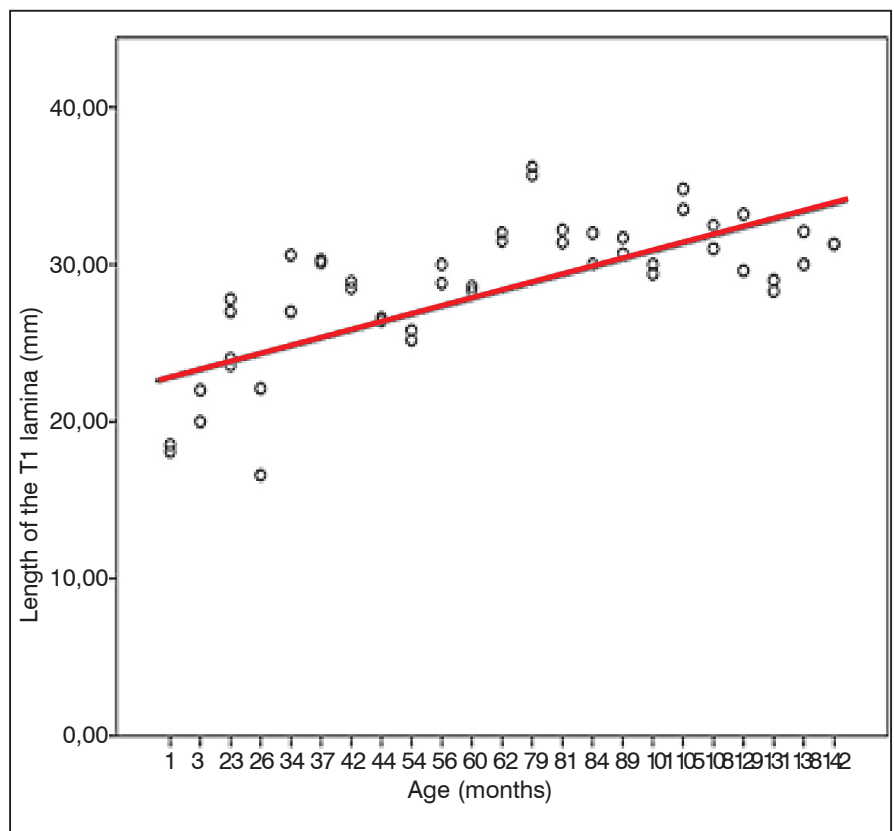

Figure 4. Variance in the length of the T1 lamina, in millimeters, by age.

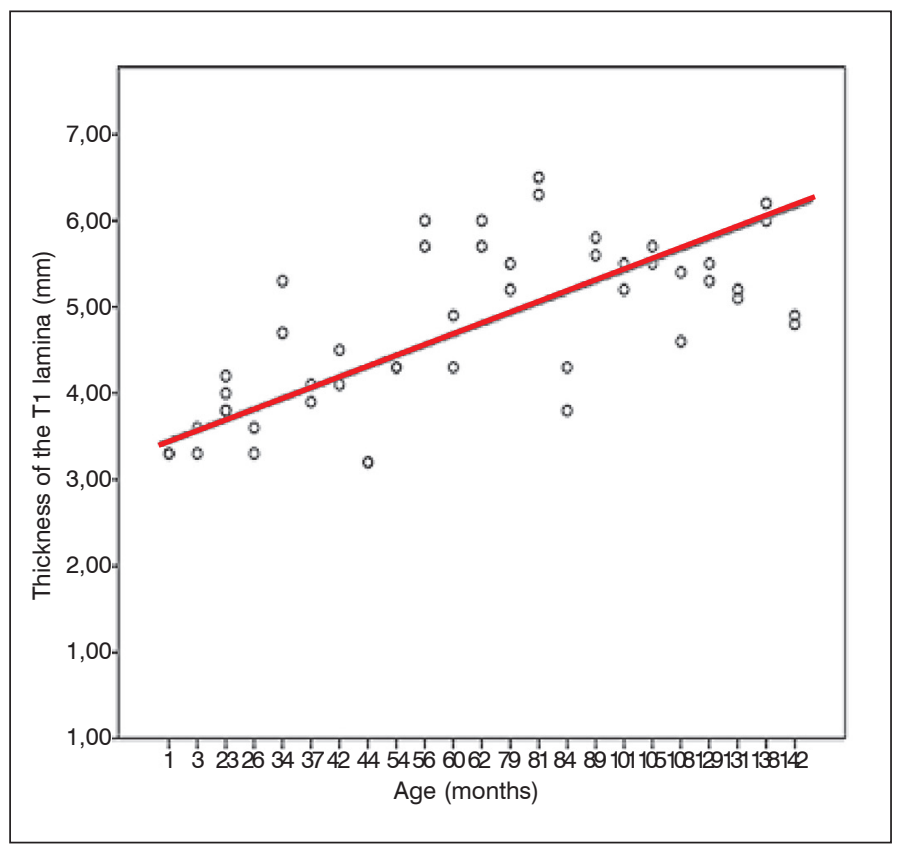

Figure 5. Variance in the thickness of the $\mathrm{T} 1$ lamina, in millimeters, by age. 
copy can assist in the placement of these screws. ${ }^{13,14}$ However, the positioning of the radioscope to obtain adequate images may be difficult in some cases. Thus, intralaminar screws are an interesting technical alternative for stabilization. Intralaminar screws are customarily used in the $\mathrm{C} 2$ lamina for $\mathrm{C} 1-\mathrm{C} 2$ arthrodesis by means of a technique developed by Wright, ${ }^{15}$ motivated by the technical difficulties of the passage of the screws in pairs (Magerl and Seemann) ${ }^{16}$ and the C2 pedicle (Harms and Melcher ${ }^{17}$ and also by the complication rates associated with these procedures. ${ }^{6}$ However, there are few case reports in the literature with the use of translaminar screws in T1 in general, a technique that is technically easier to perform. ${ }^{18,19}$

Anatomical variations in the dimensions and morphology of the T1 pedicles make surgical techniques based solely on bone repairs at the point of screw insertion potentially dangerous. ${ }^{1}$ Even under direct visualization, cortical ruptures were identified in 8-13\% of the patients. ${ }^{3,4}$

Of course, an extremely important factor for the correct realization of any surgical procedure is advance knowledge of the anatomy of the region to be operated. It is important to emphasize that there is no study in the Brazilian literature, or to our knowledge in the global literature that focuses on evaluating the characteristics of the T1 laminae in children.

Other studies to measure the laminae have been conducted by Xu et al., ${ }^{7}$ but because the study subjects were adults, and the study took place prior to the advent of intralaminar screws, the measurements were done differently, making a comparison between the studies impossible.

Our sample of 24 patients consisted of 15 males and 9 females distributed symmetrically by age, with two individuals of each age between 0 and 12 years, as can be observed in the figures.

In our study, we found a statistically significant difference $(p=0.012)$ between the average angle of attack for the passage of the laminar screw on the right side at $50.21 \pm 3.37$ (44 to 59) degrees and on the left side at $51.25 \pm 3.65$ (44 to 61) degrees. This difference may be attributed to a systematic measurement error of the software. However, clinically, because it is the length of a screw, the angle of attack was considered to be insignificant since it was less than one degree. Thus, the angles were analyzed as quantitative data, irrespective of the side measured.

The results obtained demonstrated a significant difference in the length and width of the laminae between ages, but did not identify any difference in the angulation of the laminae. The thickness of the

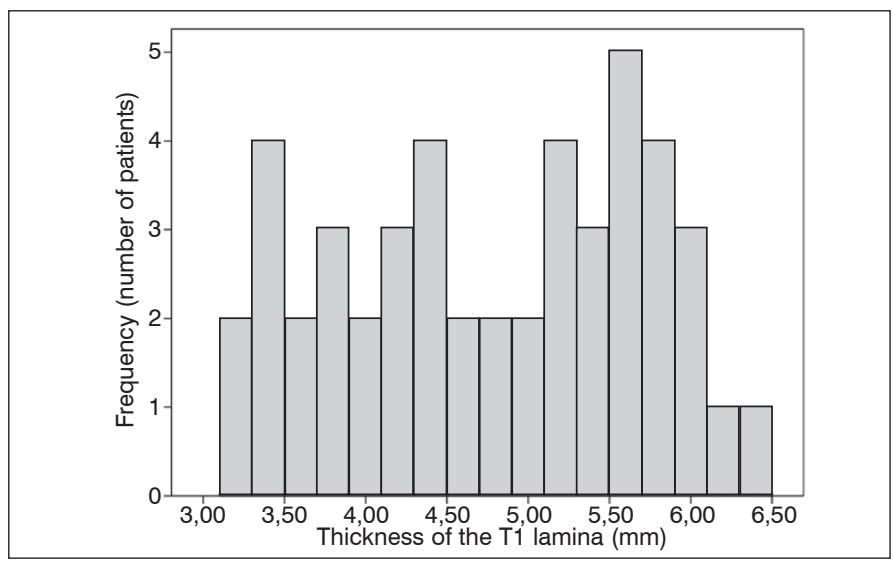

Figure 6. Frequency of thickness measurements of the T1 lamina.

T1 lamina is greater than $3.5 \mathrm{~mm}$ (minimum diameter of the screws currently commercially available) in $87.5 \%$ of the samples. In this context, the thickness of the laminae in our study population permits the passage of intralaminar screws in all the patients older than 44 months, or 3 years and 8 months, of age.

Seeking to obtain additional parameters, a new study to evaluate the mechanical resistance of intralaminar implants to the stresses in this region, performed on cadavers, could offer advances towards the safe use of intralaminary screws in this anatomical region in young patients between the ages of 0 and 12 years.

\section{CONCLUSION}

This study concluded that the length and thickness of the T1 laminas increase with age, unlike the angle of attack, which remains stable at the different ages. Based on the data obtained, we can state that in this sample, considering the implants currently available on the market, the T1 intralaminar screw is anatomically suitable for use in the laminae of patients older than 44 months of age.

All authors declare no potential conflict of interest concerning this article.

\section{REFERENCES}

1. Delamarter RB, Batzdorf U, Bohlmann HH. The C7-T1 junction: problems with diagnosis, visualization, instability, and decompression. Orthop Trans. 1989;13:218.

2. Johnston TL, Karaikovic EE, Lautenschlager EP, Marcu D. Cervical pediclescrews vs. lateral mass screws: uniplanar fatigue analysis and residual pulloutstrengths. Spine J. 2006;6(6):667-72

3. Jones EL, Heller JG, Silcox DH, Hutton WC. Cervical pedicle screws versus lateral mass screws. Anatomic feasibility and biomechanical comparison. Spine (Phila Pa 1976). 1997;22(9):977-82

4. Rhee JM, Kraiwattanapong C, Hutton WC. A comparison of pedicle and lateral mass screw construct stiffnesses at the cervicothoracic junction: a biomechanical study. Spine (Phila Pa 1976). 2005:30(21):E636-40.

5. Albert TJ, Klein GR, Joffe D, Vaccaro AR. Use of cervicothoracic junction pedicle screws for reconstruction of complex cervical spine pathology. Spine (Phila Pa 1976). 1998;23(14):1596-9.

6. Rocha ID, Jorge DMF, Pasqualin T, lutaka AS, Rodrigues MB, Oliveira RP, et al. Tomographic analysis for the placemant of laminar C2 screws. Coluna/Columna. 2008:7(2):230-234

7. Xu R, Burgar A, Ebraheim NA, Yeasting RA. The quantitative anatomy of thelaminas of the spine. Spine (Phila Pa 1976). 1999;24(2):107-13.

8. Panjabi MM, Duranceau J, Goel V, Oxland T, Takata K. Cervical human vertebrae. Quantitative three-dimensional anatomy of the middle and lower regions. Spine (Phila Pa 1976). 1991;16(8):861-9

9. Panjabi MM, Goel V, Oxland T, Takata K, Duranceau J, Krag M, et al. Human lumbar vertebrae. Quantitative three-dimensional anatomy. Spine (Phila Pa 1976). 1992;17(3):299-306.
10. Panjabi MM, Takata K, Goel V, Federico D, OxlandT, Duranceau J, et al. Thoracic human vertebrae. Quantitative three-dimensional anatomy. Spine (Phila Pa 1976). 1991:16(8):888-901.

11. Zindrick MR, Knight GW, Bunch WH, Miller MC, Butler DM, Lorenz M, et al. Factors influencing the penetration of wires into the neural canal during segmental wiring. J Bone Joint Surg Am. 1989;71(5):742-50.

12. Ebraheim NA, Xu R, Knight T, Yeasting RA. Morphometric evaluation of lower cervical pedicle and its projection. Spine (Phila Pa 1976). 1997;22(1):1-6.

13. Pelton MA, Schwartz J, Singh K. Subaxial cervical and cervicothoracic fixation techniques-indications, techniques, and outcomes. Orthop Clin North Am. 2012;43(1):19-28.

14. Koktekir E, Ceylan D, Tatarli N, Karabagli H, Recber F, Akdemir G. Accuracy of fluoroscopically-assisted pedicle screw placement: analysis of 1,218 screws in 198 patients. Spine J. 2014;14(8):1702-8

15. Wright NM. Posterior C2 fixation using bilateral, crossing C2 laminar screws: case series and technical note. J Spinal Disord Tech. 2004;17(2):158-62.

16. Magerl F, Seemann P. Stable posterior fusion of the atlas and axis by transarticular screw fixation. In: Kehr P, editor. Cervical spine. Austria: Springer-Verlag; 1987. p.322-7.

17. Harms J, Melcher RP. Posterior C1-C2 fusion with polyaxial screw and rodfixation. Spine (Phila Pa 1976). 2001;26(22):2467-71.

18. Koltz MT, Maulucci CM, Sansur CA, Hamilton DK. C7 intralaminar screw placement, an alternative to lateral mass or pedicle fixation for treatment ofcervical spondylytic myelopathy, kyphotic deformity, and trauma: A case reportand technical note. Surg Neurol Int. 2014;5:4.

19. Hong JT, Sung JH, Son BC, Lee SW, Park CK. Significance of laminar screw fixation in the subaxial cervical spine. Spine (Phila Pa 1976). 2008;33(16):1739-43. 